\title{
Spatial scale and environmental determinants in minke whale habitat use and foraging
}

\author{
Pia Anderwald ${ }^{1,2,3, *}$, Peter G. H. Evans ${ }^{2}$, Ronnie Dyer ${ }^{4}$, Andrew Dale ${ }^{5}$, \\ Peter J. Wright ${ }^{6}$, A. Rus Hoelzel ${ }^{3}$ \\ ${ }^{1}$ Coastal and Marine Research Centre, University College Cork, Irish Naval Base, Haulbowline, Cobh, Co. Cork, Ireland \\ ${ }^{2}$ Sea Watch Foundation, Ewyn Y Don, Bull Bay, Amlwch Anglesey LL68 9SD, UK \\ ${ }^{3}$ School of Biological and Biomedical Sciences, Durham University, South Road, Durham DH1 3LE, UK \\ ${ }^{4}$ Arisaig Marine Ltd., The Harbour, Arisaig, Inverness-shire PH39 4NH, UK \\ ${ }^{5}$ The Scottish Association for Marine Science, Dunstaffnage Marine Laboratory, Oban, Argyll PA37 1QA, UK \\ ${ }^{6}$ Marine Scotland, PO Box 101, 375 Victoria Road, Aberdeen AB11 9DB, UK
}

\begin{abstract}
Because pelagic prey concentrations are patchy in both space and time, predators such as marine mammals require high degrees of flexibility in their habitat use. We tested the hypothesis that minke whales Balaenoptera acutorostrata adjust their habitat use during the feeding season at different spatial scales: their overall distribution should be determined by broadscale oceanographic features, while foraging activity at finer scales should be dictated by shortterm changes in habitat conditions. Results from generalized additive models indicate that minke whale distribution off the west coast of Scotland is dependent largely on temporally variable parameters (sea surface temperature in spring, chlorophyll concentration in autumn), in addition to depth and topography. However, fine-scale foraging behaviour was dictated by the strength and direction of tidal currents. Seasonal distribution patterns according to environmental parameters were largely consistent between 2 different spatial scales, and over a time period of 15 yr. Significantly higher sighting rates occurred in areas of predicted sandeel Ammodytes marinus presence in spring, but not during the rest of the summer, while in August and September, prey samples from the core study area consisted almost entirely of sprat Sprattus sprattus. The low energetic cost of swimming in minke whales and their ability to switch between different prey according to their seasonal availability thus appears to allow them to readily respond to temporal changes in pelagic prey concentrations at different scales. This occurs through a distribution influenced by temporally variable parameters (temperature and chlorophyll concentration), combined with adjustments in foraging activity dependent on variable conditions at fine spatial scales (tides).
\end{abstract}

KEY WORDS: Habitat modelling - Balaenoptera acutorostrata $\cdot$ Prey distribution $\cdot$ North Atlantic · Baleen whale $\cdot$ Cetacean $\cdot$ Hebrides

\section{INTRODUCTION}

Patterns of habitat use in an organism relative to its size and mobility are ultimately influenced by the availability of resources. In natural habitats, physical environmental parameters often determine where and when prey are likely to be aggregated (e.g. Simard et al. 2002) (predator knowledge of this would reduce travelling time between high-density patches of prey), or can be caught most efficiently (thereby reducing handling time). Within the constraints of its mobility, a predator would therefore be expected to adjust its spatial and temporal habitat use at different scales. At large to intermediate scales, finding areas of high prey density is essential, whereas at finer scales, the optimal times and/or locations for efficient capture of prey should be selected. 
In the marine environment, suitable feeding locations for predators are patchy in both space and time and are influenced by a combination of static (e.g. water depth, bottom topography or sediment type) and temporally variable (e.g. water temperature or currents) physical environmental parameters, which influence biological processes at lower trophic levels. Pelagic predators have thus evolved to be highly mobile searchers, and some perform seasonal feeding migrations across vast distances of ocean (e.g. McKeown 1984, Baker et al. 1986, Shillinger et al. 2008). In baleen whales, breeding and feeding are both spatially and temporally segregated: breeding often occurs at lower latitudes during the winter months and feeding at higher latitudes during summer (Evans \& Stirling 2001, Stevick et al. 2002). Their distribution and abundance in an area during summer is therefore most likely a direct reflection of the availability, density and quality of their prey, which makes them well suited for a study on the influence of spatial and temporal factors on foraging behaviour.

The minke whale Balaenoptera acutorostrata shows seasonal site fidelity to summer feeding grounds (Dorsey 1983, Dorsey et al. 1990, Gill \& Fairbairns 1995), and Hoelzel et al. (1989) documented individual foraging specializations, which were associated with different habitat types. Minke whales feed on a wide range of shoaling fish, as well as krill, and appear to be able to adjust their diet to regional and seasonal changes in prey abundance (Jonsgård 1982, Lydersen et al. 1991, Haug et al. 1995, 2002, Lindstrøm et al. 1997, Neve 2000, Olsen \& Holst 2001).

Several environmental parameters may simultaneously determine changes in local prey distribution and abundance for cetaceans and other marine predators either in the short or long term. For example, variable seafloor topography, especially when combined with strong currents, can cause increased vertical mixing of water masses (Pingree \& Griffiths 1978), bringing nutrient-rich, cold bottom water into the photic zone and thus facilitating phytoplankton growth (e.g. Valiela 1995). Such areas of upwelling can represent important feeding habitat for a variety of cetacean species (e.g. Evans 1990, Baumgartner 1997). Tidal currents through deep channels or around headlands, on the other hand, can have the effect of concentrating prey, and in some areas are known to influence the local distribution of cetaceans (Mendes et al. 2002, Simard et al. 2002, Hastie et al. 2004, Cotté \& Simard 2005, Chenoweth et al. 2011) or their foraging behaviour (Evans \& Borges 1996, Pierpoint 2008). Bottom sediment type can influence the distribution of some shoaling fish such as herring
Clupea harengus (Maravelias 1999) and sandeel Ammodytes marinus (Wright et al. 1998, 2000, Holland et al. 2005), which are important prey for several cetacean species including the minke whale (Lydersen et al. 1991, Haug et al. 1995, 2002, Lindstrøm et al. 1997, 2002, Neve 2000, Olsen \& Holst 2001, Pierce et al. 2004). Different fish species also show preferences for particular temperature ranges that reflect either their own physiological adaptations or the occurrence of their zooplankton prey (Southward et al. 1988), which in turn may influence the distribution of predators such as seabirds and cetaceans (Evans 1990). Finally, when direct prey data are not readily available, remotely sensed chlorophyll concentrations can serve as a good proxy for primary productivity and, thus, as an indirect indicator of feeding conditions for species feeding at lower trophic levels, such as baleen whales (e.g. Smith et al. 1986, Thiele et al. 2000, Panigada et al. 2008). While the distribution of numerous marine predators has successfully been linked to different environmental parameters, few attempts have been made to include data on prey distribution alongside static and dynamic physical variables in habitat models and to compare results at different scales between distributional data and fine-scale tracks of individual animals (Guinet et al. 2001, Cotté et al. 2009).

In this study we investigated the spatial and temporal environmental factors that correlate to patterns of distribution and foraging activity in the minke whale. We tested the hypothesis (at 2 spatial resolutions) that seasonal distribution patterns should be determined by broad-scale geographic, oceanographic and biological features (such as mean depth, sea surface temperature [SST] and chlorophyll concentration), while foraging intensity at a fine geographic scale should be determined by local topography and short-term changes in habitat conditions, such as tidal direction and flow.

\section{MATERIALS AND METHODS}

\section{Habitat models}

The study area was located in the Hebrides on the west coast of Scotland, UK (Fig. 1), an extensive shelf area with a varied topography dominated by depths of $<200 \mathrm{~m}$ and a convoluted coastline with numerous islands that leads to highly variable tidal flows (Ellett 1979, Ellett \& Edwards 1983). Harbour porpoise Phocoena phocoena and minke whale are the 2 most commonly recorded cetacean species in the region. 


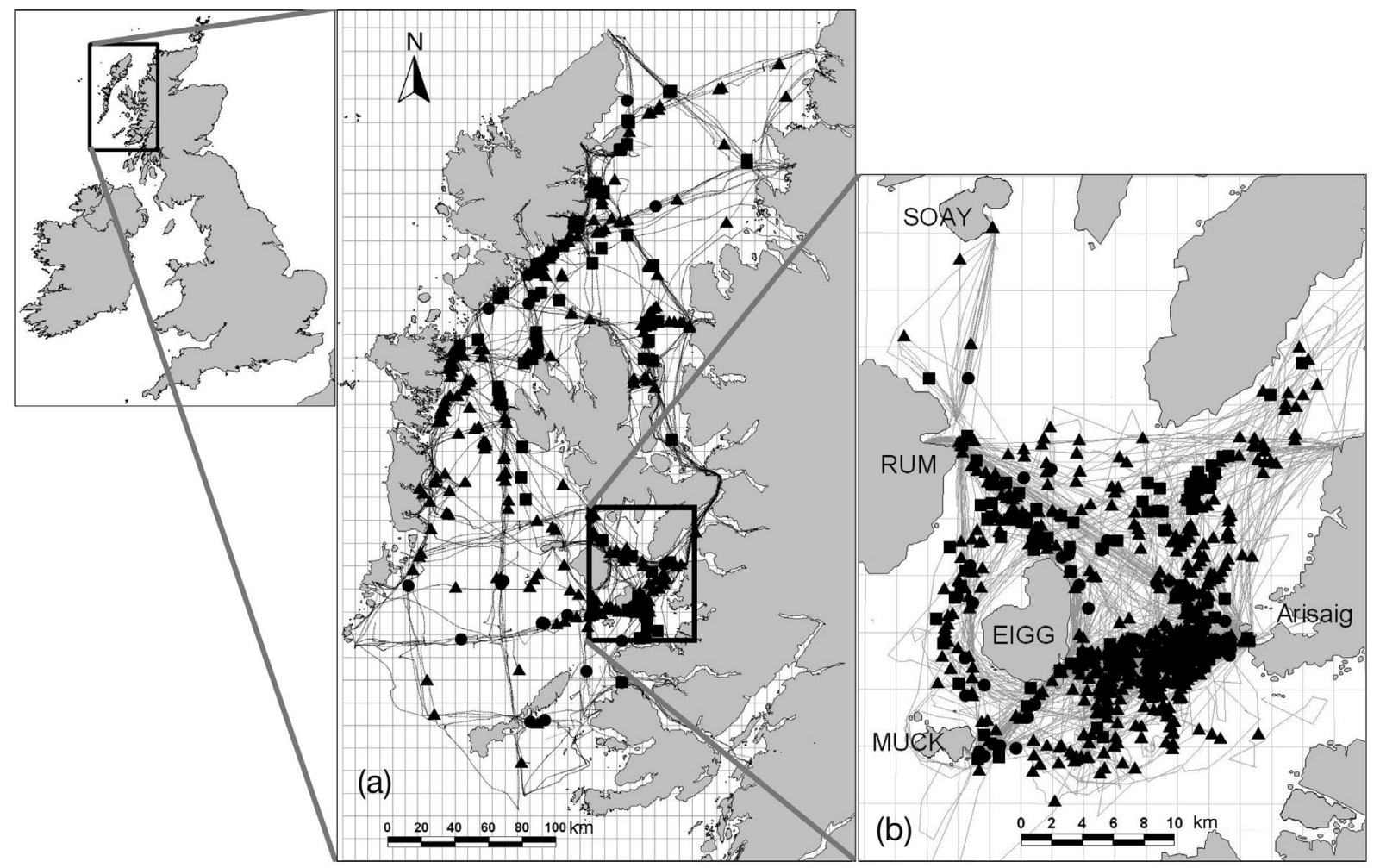

Fig. 1. Study area (a) over the entire eastern Hebrides (1993-2002) and (b) core study area around the Small Isles (1998-2007). Circles along survey routes represent sightings during early (May/June), squares during mid (July), and triangles during late

(August/September) season. Grid cells in the background indicate (a) 4' and (b) 2' cells on which analyses were based

Minke whales are present between May and October, but their numbers peak between July and September (Boran et al. 1999).

Survey data were collected from 3 main vessels (platforms): (1) the ketch 'Marguerite Explorer' (length $=20.3 \mathrm{~m}$, speed $=5$ to 8 knots [kn], eye height $=4 \mathrm{~m}$ ), from which 5 to $20 \mathrm{~d}$ line-transect and ad libitum surveys (the latter was combined with commercial wildlife watching charters, i.e. with standard recording protocols in place, but not on preplanned transect lines) were conducted over the entire eastern Hebrides during summer months (June to September) between 1993 and 2002 (although no month received coverage in every year); (2) the ferry MV 'Sheerwater' (length $=14 \mathrm{~m}$, speed $=10 \mathrm{kn}$, eye height $=3.5 \mathrm{~m}$; simultaneously used for wildlife watching en route), which operated daily in our core study area between Arisaig and the islands of Eigg, Muck, Rum (i.e. the Small Isles) and Soay (Fig. 1b) from May to September, covering the time period between August 2003 and September 2007 for the purpose of this study; and (3) 'Gwen' (length $=5 \mathrm{~m}$, speed $=6$ to $8 \mathrm{kn}$, eye height $=2 \mathrm{~m}$ ) and a variety of vessels of similar size to either 'Gwen' or MV 'Sheerwater' which were used for dedicated minke whale fieldwork (including focal sampling of individuals) in the core study area for 2 to $7 \mathrm{wk}$ each year in summer between August 2003 and July 2007. Data from surveys conducted with the 'Marguerite Explorer' were also included in the analysis of the core study area for months during which more than $10 \mathrm{~h}$ were spent around the Small Isles (August 1998 and 2002, September 1999 and July 2001).

Survey effort from platforms (1) and (3) was conducted by 2 to 3 dedicated experienced observers, including at least one of the authors. Notes were taken on preprinted recording forms every 15 to $30 \mathrm{~min}$ and at every change in direction, speed or environmental conditions. Effort records consisted of time, date, position (latitude and longitude), vessel speed and direction and sea state. Effort from platform (2) was conducted by R. Dyer and recorded as departure and arrival time at each harbour, from which time to specific waypoints was later calculated based on detailed 5 min effort recordings taken from the ferry during a total of 3 wk in August 2002 and 2003. Minke whale sightings were recorded on a standardised form from all platforms and we noted group size, time, position and behaviour/surfacing type (i.e. 'normal, fast or slow surfacing': whale swimming at nor- 
mal, fast or slow speed, respectively, with the usual surface roll; 'high arch': whale arching its back before diving, indicating a longer dive; 'lunge': surface lunge with distended throat grooves, often with fish visible above the surface).

The most important environmental parameter influencing sighting efficiency for marine mammals is sea state, especially when observing from low platforms (Buckland et al. 1993, Evans \& Wang 2002, Hammond et al. 2002, Reid et al. 2003, Evans \& Hammond 2004, Marubini et al. 2009). A correction factor for survey effort was therefore applied to observations above sea state 0 for each of the 3 main platforms (since observer height varied between vessels) by dividing sighting rates at each higher sea state by the sighting rate at sea state 0 . For additional boats, the appropriate correction factor was applied by using the most similar-sized platform. The duration of each effort leg was then divided by the appropriate correction factor for sea state to be included as an explanatory variable in each model.

Using the ArcView extension cr_tools, the study area was divided into grid cells at 2 spatial scales: 4' latitude $\times 4^{\prime}$ longitude resolution for analysis of the sightings data over the entire eastern Hebrides, and 2' latitude $\times 2$ ' longitude for the core study area (Fig. 1). The 2' cells for the Small Isles were chosen as the finest resolution that still allowed for some deviation from the normal straight route by MV 'Sheerwater', which would otherwise have resulted in erroneous assignment of some survey segments to cells at finer resolutions. On the other hand, an analysis of the 'Marguerite Explorer' data based on a grid size of 2 ' for the entire eastern Hebrides had resulted in coverage of each cell that was too low and thus inflated sighting rates. The $4^{\prime}$ cells were therefore chosen as the finest resolution for the larger study area, which still ensured representative sighting rates per cell given the lower coverage by comparison with the core study area.

Cell areas were calculated with the XTools extension in ArcView. Areas covered by land were excluded from each cell by combining cell and land polygons and subsequently deleting all land fragments from the total cell area. A British National Grid Transverse Mercator projection, centred on the study area $\left(57^{\circ} \mathrm{N}, 6^{\circ} \mathrm{W}\right)$ and with chart datum set to WGS84 (as on the GPS) was used for all calculations within ArcView. Both map and distance units were set to metres.

Effort records were linked to sightings and subsequently cut into segments of 1 min duration by using a macro in Microsoft Excel. Based on the position of its mid-point, each 1 min effort segment was then assigned to its corresponding cell at both spatial resolutions by using an additional macro. Cell summaries were calculated for all environmental parameters and linked to effort records (Table 1).

To avoid overlooking possible changes in minke whale habitat preference through the season due to uneven temporal distribution of sighting rates, separate distribution models were derived for early (May and June), mid (July) and late (August and September) season for both the entire eastern Hebrides and the core study area, resulting in a total of 6 models.

Minke whale sighting rates per cell were modelled with generalized additive models (GAMs; Hastie \& Tibshirani 1990), implemented in the mgcv library (Wood 2004, 2006) with the freeware R (R Development Core Team 2006). In comparison with generalized linear models (GLMs) or parametric linear regression, GAMs have the advantage of letting the data dictate how the shape of the dependent variable is affected by each covariate by fitting nonparametric smoother terms. They have therefore been widely applied in fisheries (e.g. Augustin et al. 1998, Maravelias 1999, Beare et al. 2002) and more recently in marine mammal studies (e.g. Bradshaw et al. 2004, Hastie et al. 2005, Panigada et al. 2008) for modelling species distribution and habitat preferences, where the relationship between explanatory and dependent variables is not expected to be linear.

Owing to an excess of zero values in the dependent variable 'sighting rate', overdispersion in the residuals was detected in 4 of the 6 separate analyses when applying models with a Poisson distribution. The overdispersion in the residuals was accounted for by applying a quasi-Poisson GAM, which provided more realistic estimates of the variance and thus significance of each smoother in the model. The residuals of the 2 spring models showed minimal overdispersion (dispersion parameter < 1.1), and minke whale sighting rates at both spatial scales for spring were therefore refitted with a Poisson distribution. Thin plate regression splines were used as penalized regression smoothers for all models. The amount of smoothing (i.e. the degrees of freedom) for each continuous explanatory variable was estimated automatically by using generalized cross-validation (GCV), but with the maximum df set to 4 to avoid overfitting. Model selection was performed in a stepwise backward procedure by minimising the unbiased risk estimator (UBRE) score (for Poisson models) and GCV score (for quasi-Poisson models), respectively (Craven \& Wahba 1979, Wood 2006). For quasi-Poisson models, the deviance explained was used for 
Table 1. Details of environmental variables used in models. For a detailed description of data processing methods, see Anderwald (2009). H: entire eastern Hebrides; C: core study area; nd: no data. TIN: Triangular Integrated Network; AVHRR: Advanced Very High Resolution Radiometer; NEODAAS: NERC Earth Observation Data Acquisition and Analysis Service; MODIS = Moderate Resolution Imaging Spectroradiometer; UKHO = UK Hydrographic Office; SST: sea surface temperature; GAM: generalized additive model

\begin{tabular}{|c|c|c|c|c|}
\hline $\begin{array}{l}\text { Environmental } \\
\text { variable }\end{array}$ & Area & Source & Resolution/years covered & Methods \\
\hline \multirow[t]{2}{*}{ Bathymetry } & $\mathrm{H}$ & $\begin{array}{l}\text { Digbath250 NW Scotland (British } \\
\text { Geological Survey) }\end{array}$ & $\begin{array}{l}1: 250000, \text { converted to } \\
200 \mathrm{~m} \text { grid }\end{array}$ & $\begin{array}{l}\text { TIN, then conversion to } \\
200 \mathrm{~m} \text { and } 70 \text { m grids; } \\
\text { mean depth per cell } \\
\text { calculated with ArcView } \\
\text { extensions 3D-Analyst } \\
\text { and Spatial Analyst } 3.3\end{array}$ \\
\hline & $\mathrm{C}$ & $\begin{array}{l}\text { Authors' own depth soundings and } \\
\text { nautical chart (Digbath250 inadequate } \\
\text { for core study area) }\end{array}$ & $70 \mathrm{~m}$ grid & \\
\hline Slope & $\mathrm{H}, \mathrm{C}$ & $\begin{array}{l}\text { Derived from bathymetry data at same } \\
\text { resolution as depth via Surface-Menu } \\
\text { in Spatial Analyst; mean and maximum } \\
\text { per cell }\end{array}$ & & \\
\hline $\mathrm{SST}$ & $\mathrm{H}, \mathrm{C}$ & AVHRR $^{a}$ (via NEODAAS) & $\begin{array}{l}1.1 \mathrm{~km}^{2} ; \text { monthly } \\
\text { composites 1993-2007 }\end{array}$ & $\begin{array}{l}\text { Spatial join (ArcView } 3.3 \text { ) } \\
\text { with mid-points of } 1 \text { min } \\
\text { effort segments, then } \\
\text { averaged for all } \\
\text { segments per cell }\end{array}$ \\
\hline \multirow[t]{2}{*}{ Chl a } & $\mathrm{H}$ & $\mathrm{nd}^{\mathrm{b}}$ & - & - \\
\hline & $\mathrm{C}$ & $\begin{array}{l}\text { SeaWiFS, MODIS Aqua (both via } \\
\text { NEODAAS) }\end{array}$ & $\begin{array}{l}1.3 \mathrm{~km}^{2},(\text { Sep } 1997-2004) \\
1.1 \mathrm{~km}^{2} \text { (May 2005-Sep } \\
2007) ; \text { monthly composites }\end{array}$ & Same as for SST \\
\hline \multirow[t]{2}{*}{ Tidal current } & $\mathrm{H}$ & TotalTide (UKHO) & $\begin{array}{l}22 \text { ports and } 26 \text { tidal } \\
\text { diamonds within study area }\end{array}$ & $\begin{array}{l}\text { Spatial join with mid- } \\
\text { points of } 1 \text { min effort } \\
\text { segments, then averaged } \\
\text { for all segments per cell } \\
\text { (split for each hour of } \\
\text { tidal cycle [spring and } \\
\text { neap]) }\end{array}$ \\
\hline & $\mathrm{C}$ & $\begin{array}{l}\text { High resolution }(<200 \mathrm{~m}) \text { 3-dimen- } \\
\text { sional (3D) hydrodynamic model forced } \\
\text { by tidal velocity and elevation from a } \\
\text { regional model (POL CS20) }{ }^{\mathrm{C}} \text { (TotalTide } \\
\text { inadequate for core study area) }\end{array}$ & $\begin{array}{l}0.5^{\prime} \text { for each hour of tidal } \\
\text { cycle (spring and neap) }\end{array}$ & \\
\hline \multirow[t]{2}{*}{$\begin{array}{l}\text { Sandeel } \\
\text { occurrence }\end{array}$} & $\mathrm{H}$ & $\begin{array}{l}\text { GAM prediction, based on relationship } \\
\text { between measured densities from day } \\
\text { grab and silt and gravel content of } \\
\text { seabed sediment (Wright et al. 2000) }\end{array}$ & $\begin{array}{l}\text { Prediction points assigned } \\
\text { to each } 4^{\prime} \text { cell }\end{array}$ & $\begin{array}{l}x \leq 0.3=\text { unlikely, } 0.3<x \\
\leq 0.7=\text { probable, } x>0.7= \\
\text { very likely; fourth cate- } \\
\text { gory for cells with no } \\
\text { prediction points. Maxi- } \\
\text { mum probability of occur- } \\
\text { rence per cell }\end{array}$ \\
\hline & $\mathrm{C}$ & $\mathrm{nd}^{\mathrm{d}}$ & - & - \\
\hline
\end{tabular}

${ }^{\mathrm{a}}$ Excluded for July (for both $\mathrm{H}$ and C) owing to missing data caused by cloud cover in most years. Cloud cover also prevented the use of composites at finer temporal resolutions (weekly or daily) for both SST and chl a

${ }^{\mathrm{b}}$ Included only in C, since no data were available at appropriate resolution before September 1997

${ }^{\mathrm{c}}$ No relationship was found between tidal current and distribution of minke whales in original models (Anderwald 2009). Cell summaries therefore recalculated without subdivision according to $2 \times 13 \mathrm{~h}$ of tidal cycle in order to achieve more representative sighting rates per cell, and to alleviate problem of zero inflation

${ }^{\mathrm{d}}$ Excluded owing to low number of prediction points in $\mathrm{C}_{i}$ no quantitative data on distribution of other potential prey species were available 
model selection in addition to the GCV score. Nonsignificant variables were retained in the model if they contributed to minimizing the UBRE or GCV score and (in the latter case) increased the deviance explained. Residuals of the final models were plotted against each explanatory variable to check for residual patterns. Since the data were divided into 3 separate models per season, the significance values of each explanatory variable in the final models were Bonferroni-corrected and provided a new p-value of 0.0167 .

Exploratory analysis included Spearman's rank correlation coefficients and pair-plots to check for both linear and (based on pair-plots) nonlinear correlations between continuous explanatory variables (Table 2). Sea state corrected time spent on effort and kilometres travelled per cell were included as correction factors in all models to account for biases in spatial and temporal coverage of different cells. Since the same amount of effort with respect to time spent watching and distance travelled in a cell with reduced sea area (i.e. adjoining land) results in better coverage than an equivalent amount of effort in a cell entirely covered by sea, cell area covered by sea was included as an additional correction factor.

Inclusion of the MV 'Sheerwater' data in the core study area resulted in strong correlations (Spearman's $\left.r_{S}: 0.788<r_{S}<0.927\right)$ between the correction variables 'sea state corrected time' and 'length of survey track' per cell. The 2 variables could therefore not be included in the same model. The decision on which parameter to include was based on which improved the model the most (i.e. led to a greater decrease in the UBRE or GCV score and increase in explained deviance). For the May/June and August/ September models, this was the number of sea state corrected hours; for the July model, it was the distance travelled per cell. No strong correlations were found between any of the other selected explanatory variables $\left(\mathrm{r}_{\mathrm{S}}<0.6\right)$.

\section{Tracks of individuals}

The aim of the second analysis was to investigate which environmental parameters determined minke whale behaviour - notably foraging (including feed- ing and searching) versus travelling - to help characterize foraging habitat in the context of distributional data. Individual whales were followed for as long as possible, while recording their surfacing times to the nearest second, their position and surfacing type ('normal or fast surfacing' or 'high arch' before dive, 'surface feeding': lunge with distended throat grooves, fish often visible). Any possibilities of missed surfacings were noted and those dives were subsequently excluded from analysis. All whales were followed at a distance of 30 to $100 \mathrm{~m}$, taking care to remain on as constant a course and speed as possible in order to avoid influencing the focal animal's behaviour or dive pattern.

The study area around the Small Isles was divided into cells of $0.5^{\prime}$ latitude $\times 0.5^{\prime}$ longitude (Fig. 2), and the surfacing positions of individual whales were linked to the same environmental parameters as the 1 min effort segments for the habitat models covering the core study area (Table 1). The direction of the tidal current was included as an additional categorical explanatory variable. 
Owing to the variability in dive patterns between individuals and the possibility of whales switching between different behaviours during a focal follow (the period when an individual is followed for an extended period of time), no attempt was made to distinguish between foraging and travelling whales in the field. Instead, foraging or travelling behaviour was assigned based on the plotted track line of each individual. According to area-restricted search, an animal increases the turning rate in its search path after food intake, and thus remains longer in highdensity prey patches (Tinbergen et al. 1967, Kareiva \& Odell 1987, Walsh 1996, Fauchald \& Tveraa 2003). It was therefore assumed that foraging whales would, on average, spend more time in a given area compared with those travelling and thus moving in a more direct line. The number of $0.5^{\prime}$ cells covered by the track line of each focal follow was therefore divided by its duration, giving a rate of 'number of cells visited per hour'. The resulting frequency distribution of the number of cells visited per hour roughly divided individuals into 2 groups (data not shown): whales moving at a rate of $<5$ cells $\mathrm{h}^{-1}$ were classed as foraging, whereas whales that covered $>10$ cells $\mathrm{h}^{-1}$ were classed as travelling. The tracks of individuals moving at intermediate rates of 5 to 10 cells $\mathrm{h}^{-1}$ were visually inspected for a possible switch between foraging and travelling, based on a change from moving in a straight line to fine-scale use of cells combined with an abrupt change in the direction of movement. All other tracks within this category were classed as foraging. These assumptions were then validated independently by checking that any surfacings associated with feeding behaviour only occurred during focal follows classed as foraging.

Typical breathing sequences in minke whales consist of 3 to 6 short dives followed by one longer dive (typically 3 to 13 min; see Gunnlaugsson 1989, Joyce et al. 1990, Anderwald et al. 2008). However, only longer dives (i.e. not within a breathing sequence) are likely to be relevant in determining the foraging path and behaviour of individuals. The cut-off value between breathing sequences and potential foraging dives was determined by a marked decline in overall

frequencies of dive duration (found to be at $50 \mathrm{~s}$, Anderwald 2009). Only surfacing positions preceding dives of $>50 \mathrm{~s}$ in duration, and part of focal follows lasting at least $30 \mathrm{~min}$ or including at least 10 dives of $>50 \mathrm{~s}$ each, were therefore considered for the analysis.

To reduce the risk of spatial auto-correlation, the analysis was based on grid cells rather than single dives: all long dives (i.e. $>50$ s) of an individual within a $0.5^{\prime}$ cell were summarized and the resulting means of the continuous explanatory variables included in the model. This resulted in each cell being represented only once per individual per day (Fig. 2). A GAM with a binomial error distribution indicated approximately linear relationships between the continuous explanatory variables and the response variable. The model was therefore refitted with a logistic regression. Before including the environmental parameters into the GLM, a univariate ANOVA with 'Behaviour' (forage versus travel) as the explanatory variable was performed for each continuous parameter in turn in order to examine its residual pattern. A natural log transformation of chlorophyll a (chl a), maximum slope and tidal current data ensured that the residuals of all 3 parameters followed a Poisson distribution, while SST and 
mean depth did not require transformation. All explanatory variables were simultaneously included in the logistic regression, and model selection was performed in a stepwise backward manner first by applying Akaike's information criterion (AIC; Burnham \& Anderson 2002) and then the deviance test.

\section{RESULTS}

\section{Habitat models}

A total of 356 minke whale sightings (comprising 409 individuals) during $1515 \mathrm{~h}$ of survey effort were included in the analysis from the 'Marguerite Explorer' data over the entire eastern Hebrides between 1993 and 2002 (Fig. 1a). Survey effort around the Small Isles amounted to a total of $2326 \mathrm{~h}$ with 765 minke whale sightings between 1998 and 2007 (Fig. 1b). Of these, data from MV 'Sheerwater' between 2003 and 2007 contributed 1688 h (72.5\%) and $376(49 \%)$ sightings; dedicated field work from 'Gwen' and other vessels between 2003 and 2007 accounted for $572 \mathrm{~h}(24.5 \%)$ and 342 (45\%) sightings, and data from 'Marguerite Explorer' between 1998 and 2002 provided $66 \mathrm{~h} \mathrm{(3 \% )} \mathrm{of} \mathrm{effort} \mathrm{and} 47$ (6\%) sightings. Highest sighting rates from all platforms occurred during July and August.

Minke whale sighting rates from the 2 independent sources - MV 'Sheerwater' and dedicated fieldwork from 'Gwen' (and other vessels during 2003 to 2007) - were positively correlated for all months of simultaneous data collection within the core study area (Spearman's correlation: $r_{S}=0.803, p=0.009$ ). Sighting rates along the ferry route could therefore be viewed as representative of the whole area around the Small Isles, so the data sets were pooled.

\section{Entire eastern Hebrides}

A common feature among all 3 seasonal models for the entire eastern Hebrides was that none of the tidal parameters used was relevant in determining minke whale sighting rates per cell (Table 3). Although retained in some models for better fit, they were not

Table 3. Summaries for final generalized additive models for data from 'Marguerite Explorer'; 4' cells over entire study area. -: parameter not included in final model; na: not applicable for model in question. ${ }^{*} p<0.0167$ (Bonferroni correction: 0.05/3), ${ }^{* *} \mathrm{p}<0.005,{ }^{* * *} \mathrm{p}<0.001$

\begin{tabular}{|c|c|c|c|}
\hline & $\begin{array}{c}\text { June } \\
1995,2000(\mathrm{n}=174)\end{array}$ & $\begin{array}{c}\text { July } \\
1993,1994,1998(\mathrm{n}=212)\end{array}$ & $\begin{array}{c}\text { August and September } \\
\text { 1993-1994, 1996-1997, } 2002(\mathrm{n}=738)\end{array}$ \\
\hline Parametric coefficients & & - Estimate $( \pm \mathrm{SE})$ & \\
\hline Intercept & $-6.283( \pm 1.031)^{* * *}$ & $-1.629( \pm 0.360)^{* * *}$ & $-2.625( \pm 0.459)^{* * *}$ \\
\hline Year: & & - & \\
\hline 2000 (vs. 1995) & $3.860( \pm 1.465)^{*}$ & na & na \\
\hline 1994 (vs. 1993) & na & na & $1.614( \pm 0.461)^{* * *}$ \\
\hline 1996 (vs. 1993) & na & na & $1.680( \pm 0.454)^{* * *}$ \\
\hline 1997 (vs. 1993) & na & na & $2.021( \pm 0.481)^{* * *}$ \\
\hline 2002 (vs. 1993) & na & na & $1.856( \pm 0.554)^{* * *}$ \\
\hline Month: September (vs. August) & na & na & $-0.611( \pm 0.254)^{*}$ \\
\hline \multicolumn{4}{|l|}{ Sandeel probability: } \\
\hline Probable (vs. unlikely) & $3.091( \pm 0.839)^{* * *}$ & $-8.654( \pm 52.14)$ & - \\
\hline Very likely (vs. unlikely) & $2.777( \pm 0.778)^{* * *}$ & $-0.284( \pm 0.500)$ & - \\
\hline No data (vs. unlikely) & $0.661( \pm 0.868)$ & $0.116( \pm 0.311)$ & - \\
\hline Spring vs. neap tide & $0.803( \pm 0.610)$ & $0.449( \pm 0.554)$ & $-0.828( \pm 0.377)$ \\
\hline \multicolumn{2}{|l|}{ Smooth terms } & $-\mathrm{X}^{2}$ (estimated df) & \\
\hline Depth (mean) & - & $10.320(1.91)^{*}$ & $20.084(3.68)^{* * *}$ \\
\hline Slope (mean) & $15.875(3.77)^{* *}$ & - & $9.959(3.70)$ \\
\hline SST & $15.507(3.81)^{* *}$ & na & $21.343(3.83)^{* * *}$ \\
\hline Tidal height difference & - & $6.111(2.51)$ & $4.127(1.82)$ \\
\hline Tidal current & - & - & $1.546(2.58)$ \\
\hline Duration (sea state corrected) & - & $6.545(2.41)$ & $31.523(2.42)^{* * *}$ \\
\hline Distance $(\mathrm{km})$ travelled per cell & $2.265(1.82)$ & $5.552(2.95)$ & $3.302(1.49)$ \\
\hline Cell area & $3.566(2.48)$ & $0.896(1)$ & - \\
\hline Dispersion parameter & na & 1.451 & 1.585 \\
\hline Deviance explained & $64.2 \%$ & $26.1 \%$ & $29.1 \%$ \\
\hline
\end{tabular}


(a) June
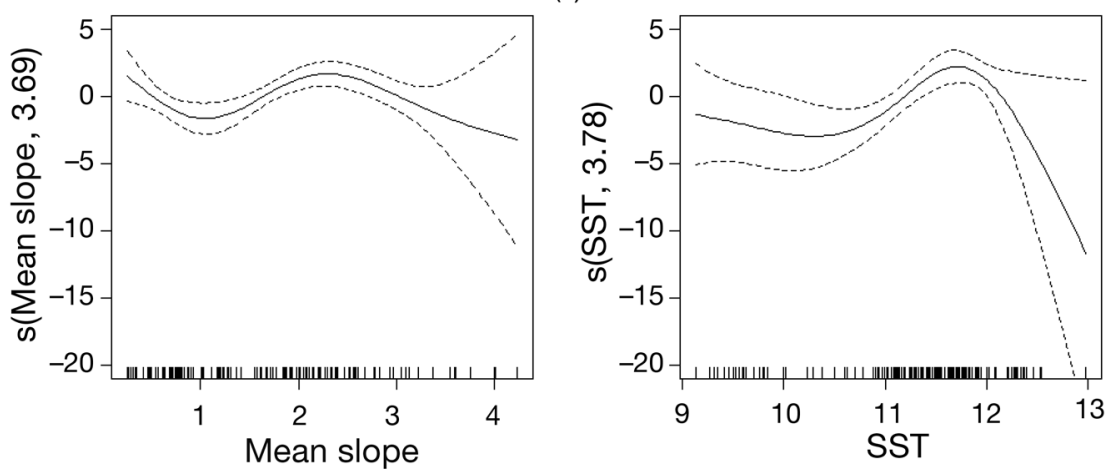

(c) August \& September
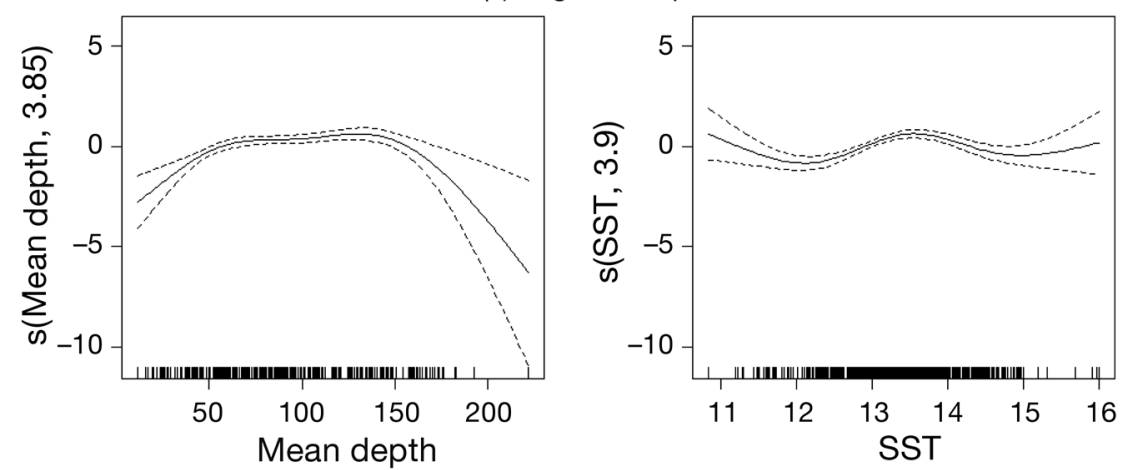

(b) July

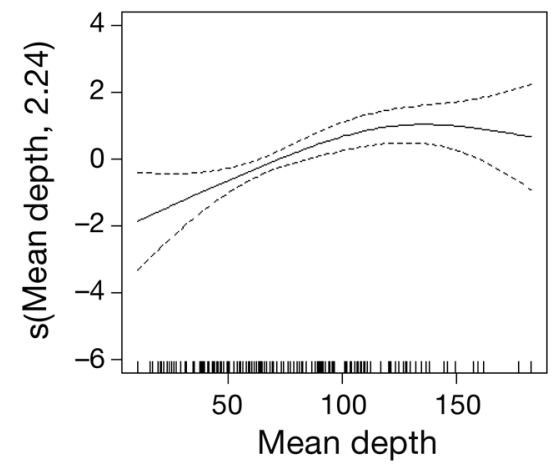

Fig. 3. Generalized additive model smoothing curves for significant environmental parameters (after Bonferroni correction) on minke whale Balaenoptera acutorostrata sighting rates (ind. $\mathrm{h}^{-1}$ ) per cell for the 3 seasonal models over the entire eastern $\mathrm{He}$ brides (smoothers for correction terms not shown). Broken lines represent $2 \times$ $\mathrm{SE}$ ranges around the main effects. The degrees of freedom for each smoothing curve are indicated on the $y$-axis. Vertical dashes on the $x$-axis represent the distribution of the explanatory variable significant when corrected for other explanatory variables. In June, minke whale sighting rates were significantly higher in cells with 'probable' and 'very likely' sandeel occurrence compared with cells with 'unlikely' sandeel presence, whereas there was no difference between cells with 'unlikely' sandeel occurrence and no prediction points (Table 3). For July, sandeel occurrence was still retained in the model for better fit even though it was no longer significant, and for August/September, this factor was removed from the model altogether (Table 3), which indicated that sandeels are important to minke whales only early in the season.

Smooth terms also showed differences in their relevance between months. Seafloor topography only played a role for the month of June, when whales showed a preference for intermediate slopes of around 2 to $2.5^{\circ}$ (Fig. 3a). During summer and autumn, however, depth better explained minke whale distribution. Sighting rates increased with water depth (from 50 to $60 \mathrm{~m}$ and above, reaching a plateau at 110 to 120 m; Fig. 3b) in July, when depth was the only significant continuous variable in the model. During August/September, the smoothing curve for depth exhibited an overall bell-shaped form, showing a broad preference by whales for waters of 50 to $150 \mathrm{~m}$ deep (Fig. 3c). SST was important in explaining minke whale distribution during both June and August/September. During June, the whales showed a preference for temperatures at the higher end of the scale at around 11.5 to $12^{\circ} \mathrm{C}$ (Fig. 3a), and in August/September for intermediate values between 13 and $14^{\circ} \mathrm{C}$ (Fig. 3C).

The model that best explained minke whale distribution over the whole of the Hebrides was for June and accounted for $64.2 \%$ of the deviance. The models for July and August/September, on the other hand, only explained 26.1 and $29.1 \%$ of the deviance, respectively, despite the high number of explanatory variables retained in the latter (Table 3 ).

\section{Core study area}

While the factor 'year' was irrelevant for spring, significantly more whales were seen per unit effort spent in the month of July in 2004 and 2007 compared with 2001. By contrast, there was a large and significant decline in sighting rates during August/September for the years 2005 to 2007 compared with 1998 (Table 4).

The smoothing curve for depth in July showed the same shape as for the same month in the model for the entire eastern Hebrides; both reached a plateau at around $100 \mathrm{~m}$ (Fig. 4b). For August/September, the shape of the depth curve was similar, but reached a peak at 70 to $80 \mathrm{~m}$ and remained level up to $100 \mathrm{~m}$ 
Table 4. Summaries for final generalized additive models for core study area around the Small Isles, based on 2' cells. max.: maximum; -: parameter not included in final model; na: not applicable for model in question. ${ }^{*} \mathrm{p}<0.0167$ (Bonferroni correction: $0.05 / 3),{ }^{* *} p<0.005,{ }^{* * *} p<0.001$

\begin{tabular}{|c|c|c|c|}
\hline & $\begin{array}{l}\text { May and June } \\
2004-07(\mathrm{n}=440)\end{array}$ & $\begin{array}{c}\text { July } \\
\text { 2001, 2004-07 }(\mathrm{n}=305)\end{array}$ & $\begin{array}{l}\text { August and September } \\
1998-99,2002-07(\mathrm{n}=814)\end{array}$ \\
\hline Parametric coefficients & & _ Estimate $( \pm \mathrm{SE})$ & \\
\hline Intercept & $-2.688( \pm 0.211)^{* * *}$ & $-2.954( \pm 0.694)^{* * *}$ & $-0.035( \pm 0.297)$ \\
\hline Year: & - & & \\
\hline 2004 (vs. 2001) & na & $2.767( \pm 0.696)^{* * *}$ & na \\
\hline 2005 (vs. 2001) & na & $-0.733( \pm 1.116)$ & na \\
\hline 2006 (vs. 2001) & na & $1.716( \pm 0.718)$ & na \\
\hline 2007 (vs. 2001) & na & $1.742( \pm 0.699)^{*}$ & na \\
\hline 1999 (vs. 1998) & na & na & $1.017( \pm 0.444)$ \\
\hline 2002 (vs. 1998) & na & na & $-0.045( \pm 0.399)$ \\
\hline 2003 (vs. 1998) & na & na & $-0.209( \pm 0.421)$ \\
\hline 2004 (vs. 1998) & na & na & $0.096( \pm 0.301)$ \\
\hline 2005 (vs. 1998) & na & na & $-2.504( \pm 0.575)^{* * *}$ \\
\hline 2006 (vs. 1998) & na & na & $-2.524( \pm 0.510)^{* * *}$ \\
\hline 2007 (vs. 1998) & na & na & $-2.607( \pm 0.684)^{* * *}$ \\
\hline Month: September (vs. August) & - & na & $-0.772( \pm 0.222)^{* * *}$ \\
\hline Spring vs. neap tide & - & - & $0.165( \pm 0.143)$ \\
\hline Smooth terms & . & $\mathrm{X}^{2}$ (equivalent df) & \\
\hline Depth (mean) & $6.627(3.17)$ & $29.879(2.28)^{* * *}$ & $32.181(2.66)^{* * *}$ \\
\hline Slope (max.) & $1.211(1.50)$ & $16.497(2.43)^{* * *}$ & $5.123(1)$ \\
\hline SST & $11.942(2.71)^{*}$ & - & $0.768(1)$ \\
\hline Chl a & $0.395(1)$ & - & $16.455(3.31)^{* * *}$ \\
\hline Duration (sea state corrected) & $2.385(2.47)$ & - & $11.859(1)^{* * *}$ \\
\hline Distance $(\mathrm{km})$ travelled per cell & - & $7.391(1)^{*}$ & - \\
\hline Cell area & - & $8.157(3.51)$ & - \\
\hline Dispersion parameter & na & 2.712 & 2.275 \\
\hline Deviance explained & $14.9 \%$ & $46.3 \%$ & $41.6 \%$ \\
\hline
\end{tabular}

(Fig. 4c). This depth range coincides with a deep channel between Arisaig and the Isle of Eigg (Fig. 2). Topography only affected minke whale sighting rates during the month of July, during which the maximum slope showed a bell-shaped form around a peak of 15 to $17^{\circ}$ (Fig. $4 \mathrm{~b}$ ).

Both temporally variable continuous parameters (SST and chlorophyll) were important predictors of relative minke whale abundance at particular stages of the season. SST was the only significant variable in the May/June model, when whales showed a preference for water temperatures around $11^{\circ} \mathrm{C}$ (Table 4, Fig. 4a). In contrast to the entire eastern Hebrides, however, SST was not significant in the Small Isles model for August/September. Instead, chlorophyll concentration (data for which had not been available for the earlier years of coverage) played a highly significant role in determining minke whale sighting rates during the latter part of the season: numbers of whales per unit effort showed a steady increase from a chl a concentration of $1 \mathrm{mg} \mathrm{m}^{-3}$ to a peak at $3 \mathrm{mg}$ $\mathrm{m}^{-3}$ (Fig. 4c).
The explanatory power of the 3 seasonal models was reversed for the Small Isles compared with the entire eastern Hebrides. The spring model, in which SST was the only significant variable, explained only $14.9 \%$ of the deviance, making it the poorest of all 6 models. On the other hand, both the July and August/September models performed better for the Small Isles than for the whole area, with $46.3 \%$ of the deviance explained for July and $41.6 \%$ for August/ September, respectively (Table 4).

\section{Tracks of individuals}

A total of 26 track lines fulfilled the duration criterion of at least $30 \mathrm{~min}$ or the inclusion of at least 10 dives of $>50$ s per dive. Based on their track lines (i.e. the number of cells visited per unit time), the behaviour during 19 focal follows (73\%) was classed as foraging, and 4 focal follows $(15 \%)$ were classed as travelling. Three sequences (12\%) appeared to include a transition between foraging and travelling or vice 
(a) May \& June

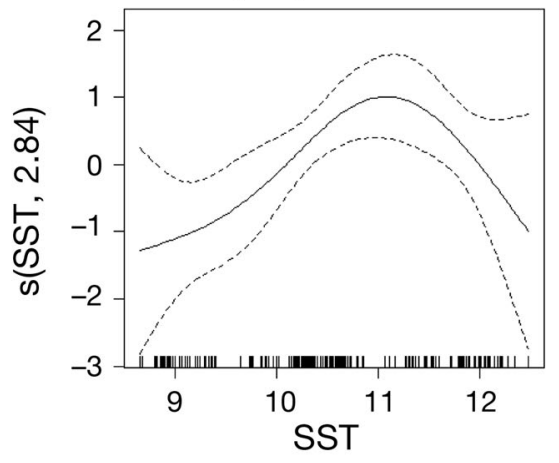

(c) August \& Sẹptember

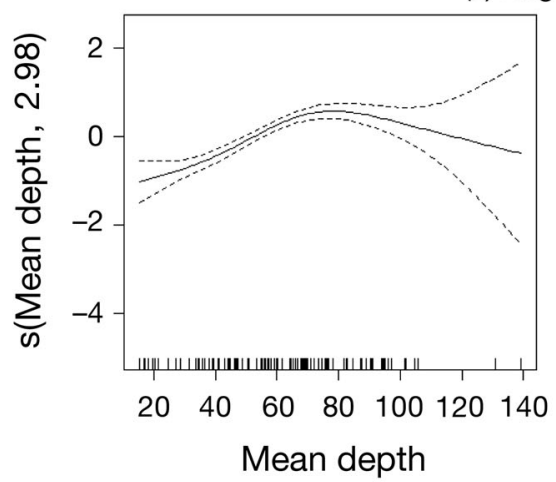

(b) July
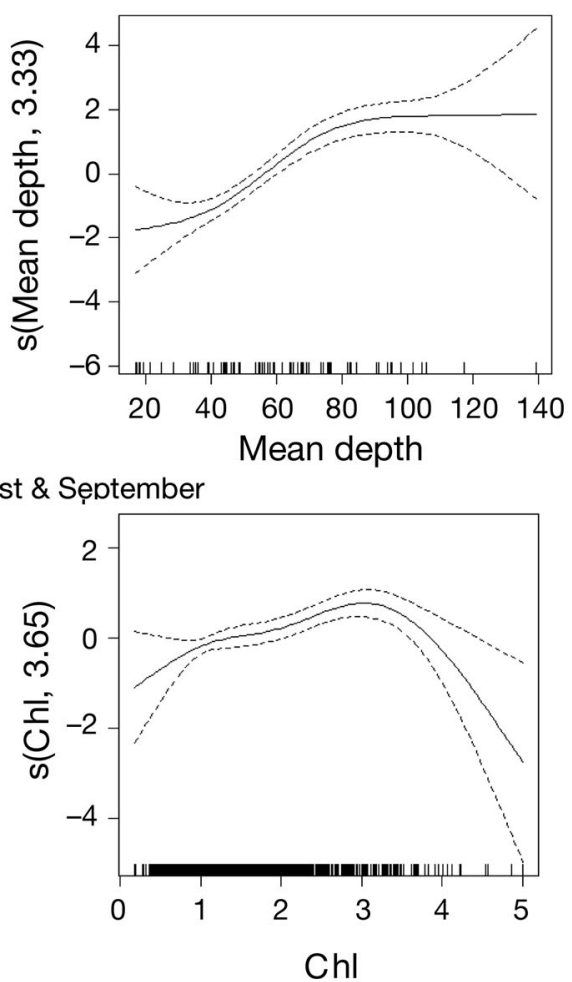

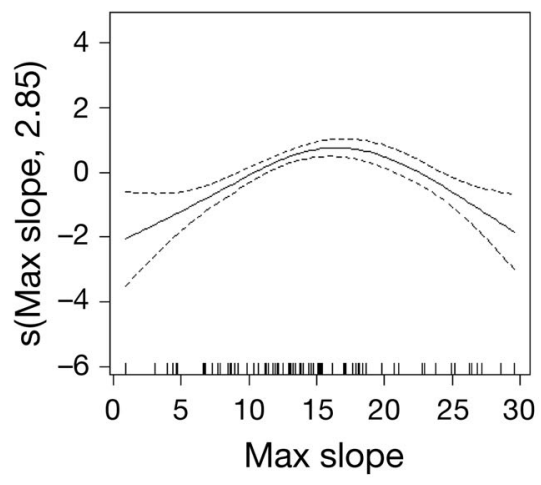

Fig. 4. Generalized additive model smoothing curves for significant parameters (after Bonferroni correction) on minke whale Balaenoptera acutorostrata sighting rates (ind. $\mathrm{h}^{-1}$ ) per cell for the 3 seasonal models covering the core study area around the Small Isles (smoothers for correction terms not shown). Broken lines represent SE ranges around the main effects. The degrees of freedom for each smoothing curve are indicated on the $y$-axis. Vertical dashes on the $x$-axis represent the distribution of the explanatory variable versa, based on an abrupt change in the direction of the whales' movement combined with a switch from moving in a straight line to a more unpredictable course in which fewer cells were visited per unit time.

The duration of successful focal follow sequences ranged from $26 \mathrm{~min}$ to $2 \mathrm{~h} 54 \mathrm{~min}$, which amounted to a total of 1552 recorded dives (32.4 h), 593 of which exceeded $50 \mathrm{~s}$. The maximum dive time for which any possibility of a missed surfacing could be excluded was $10 \mathrm{~min} 10 \mathrm{~s}$ (Table 5). Sixteen individuals could be identified during focal follows by using photoidentification. Of these, only 1 individual was followed on 2 consecutive days (S06 in 2006; Table 5); focal follows of all other identified individuals were confined to a single day.

The only significant parameters included in the final logistic regression model were direction and strength of tidal current (Table 6): minke whales were more likely to forage in areas of strong tidal currents (regression coefficient $=1.1713, \mathrm{SE}=0.3722$; Fig. 5), and travelling was more likely in areas in which the current flow was in a north-westerly direction as opposed to an easterly (the reference level) direction (regression coefficient $=-3.0781, \mathrm{SE}=$ 1.2268). The model including both tidal strength and direction explained almost half of the total variance in the data (Nagelkerke $\mathrm{R}^{2}=0.458$ ).

\section{DISCUSSION}

As expected for a highly mobile baleen whale, habitat modelling results indicated that minke whale distribution on the west coast of Scotland during the summer feeding season was influenced simultaneously by both fixed and temporally variable environmental parameters that are thought to determine the spatial and temporal availability of pelagic prey concentrations. However, the relative importance of these variables changed through the season, both over the entire eastern Hebrides and within the smaller core study area around the Small Isles. Despite the differences in spatial scale ( 4 ' versus 2'), coverage (the entire eastern Hebrides with a large area and relatively low temporal coverage, and the Small Isles with extensive temporal coverage) and study period (large area from 1993 to 2002, and Small Isles from 1998 to 2007 but mainly 2003 to 2007), the GAM results for each part of the season were surprisingly consistent between the entire eastern Hebrides and the core study area. This suggests that the findings for minke whale habitat use within a comparatively small but highdensity area are generally applicable for the species across the entire west coast of Scotland and over an extended time period (15 yr). 
Table 5. Summaries of minke whale Balaenoptera acutorostrata focal follows conducted around the Small Isles between 2003 and 2007. Max.: maximum; ID: identification; f: foraging; t: travelling

\begin{tabular}{|c|c|c|c|c|c|c|c|c|}
\hline $\begin{array}{l}\text { Individual } \\
\text { no. }\end{array}$ & $\begin{array}{c}\text { Individual } \\
\text { identification }\end{array}$ & $\begin{array}{c}\text { Date } \\
\text { (d.mo.yr) }\end{array}$ & $\begin{array}{c}\text { Start } \\
\text { time }(\mathrm{h})\end{array}$ & $\begin{array}{c}\text { End } \\
\text { time }(\mathrm{h})\end{array}$ & $\begin{array}{l}\text { Duration } \\
\text { (min) }\end{array}$ & $\begin{array}{l}\text { Max. dive } \\
\text { time (s) }\end{array}$ & $\begin{array}{c}\text { No. } \\
\text { surfacings }\end{array}$ & $\begin{array}{l}\text { No. dives } \\
>50 \mathrm{~s}\end{array}$ \\
\hline $1 \mathrm{f}$ & Unidentified & 4.8 .2003 & $16: 47$ & $17: 13$ & 26 & 242 & 21 & 10 \\
\hline $2 \mathrm{f}$ & Unidentified & 4.8.2003 & $19: 27$ & $20: 15$ & 48 & 250 & 47 & 19 \\
\hline $3 t$ & Unidentified & 5.8 .2003 & $19: 28$ & $20: 03$ & 35 & 335 & 26 & 10 \\
\hline $4 \mathrm{f}$ & Unidentified & 6.8 .2003 & $10: 49$ & $11: 29$ & 40 & 167 & 35 & 10 \\
\hline $5 \mathrm{f}$ & Unidentified & 7.8 .2003 & $10: 44$ & $11: 48$ & 64 & 320 & 49 & 24 \\
\hline $6 \mathrm{f}$ & F02 & 10.8 .2003 & $11: 49$ & $12: 59$ & 70 & 422 & 39 & 17 \\
\hline $8 \mathrm{f} / \mathrm{t}$ & F03 & 11.8 .2003 & $11: 44$ & $14: 32$ & 168 & 420 & 106 & 50 \\
\hline $9 \mathrm{f}$ & F05 & 11.8 .2003 & $15: 53$ & $16: 42$ & 49 & 343 & 47 & 17 \\
\hline $10 \mathrm{f}$ & N06 & 11.8 .2003 & $17: 38$ & $18: 26$ & 48 & 280 & 35 & 14 \\
\hline $11 \mathrm{f}$ & S05 & 12.8 .2003 & $10: 44$ & $11: 11$ & 27 & 124 & 31 & 14 \\
\hline $12 \mathrm{f}$ & W02 & 12.8 .2003 & $12: 38$ & $13: 16$ & 38 & 202 & 40 & 12 \\
\hline $13 \mathrm{f}$ & N17 & 12.8 .2003 & $\begin{array}{l}13: 16 \\
14: 12\end{array}$ & $\begin{array}{l}13: 31 \\
15: 41\end{array}$ & 104 & 279 & 72 & 42 \\
\hline $14 \mathrm{f}$ & F04 & 12.8 .2003 & $16: 25$ & $18: 26$ & 120 & 228 & 95 & 38 \\
\hline $15 \mathrm{t}$ & S01 & 22.8.2004 & $\begin{array}{l}11: 41 \\
12: 08\end{array}$ & $\begin{array}{l}11: 51 \\
13: 29\end{array}$ & 91 & 360 & 103 & 33 \\
\hline $16 \mathrm{t}$ & Unidentified & 22.8.2004 & $18: 26$ & $19: 11$ & 45 & 150 & 30 & 22 \\
\hline $18 \mathrm{t}$ & B01 & 31.8.2004 & $12: 09$ & $13: 41$ & 92 & 335 & 47 & 21 \\
\hline $20 \mathrm{f} / \mathrm{t}$ & Unidentified & 10.9 .2004 & $14: 58$ & $16: 23$ & 85 & 435 & 41 & 19 \\
\hline $22 \mathrm{f}$ & F15 & 9.8 .2005 & $08: 58$ & 09:42 & 44 & 277 & 27 & 9 \\
\hline $23 \mathrm{f}$ & Unidentified & 11.8 .2005 & $08: 57$ & $11: 05$ & 128 & 463 & 107 & 37 \\
\hline $24 \mathrm{f}$ & F14 & 11.8 .2005 & $16: 28$ & $17: 07$ & 39 & 255 & 32 & 12 \\
\hline $25 \mathrm{f}$ & Unidentified & 14.8 .2005 & $18: 43$ & $19: 34$ & 51 & 333 & 43 & 12 \\
\hline $26 \mathrm{f}$ & N23 & 4.9 .2005 & $17: 56$ & 20:06 & 130 & 430 & 127 & 28 \\
\hline $27 \mathrm{f}$ & S06 & 11.8 .2006 & $15: 51$ & $16: 53$ & 62 & 251 & 43 & 22 \\
\hline$f / t$ & & $\begin{array}{l}12.8 .2006 \\
12.8 .2006\end{array}$ & $\begin{array}{l}11: 48 \\
14: 24\end{array}$ & $\begin{array}{l}13: 59 \\
15: 07\end{array}$ & 174 & 389 & 168 & 52 \\
\hline $28 \mathrm{f}$ & F19 & 20.7 .2007 & $13: 35$ & $15: 49$ & 134 & 610 & 125 & 41 \\
\hline $30 \mathrm{f}$ & F26 & 23.7 .2007 & $10: 41$ & $11: 12$ & 31 & 380 & 16 & 8 \\
\hline Mean \pm SD & & & & & $75 \pm 44$ & $318 \pm 109$ & $60 \pm 40$ & $23 \pm 13$ \\
\hline Total & & & & & $32.4 \mathrm{~h}$ & & 1552 & 593 \\
\hline
\end{tabular}

Table 6. Final model of logistic regression on minke whale Balaenoptera acutorostrata behaviour (foraging versus travelling). AIC: Akaike's information criterion

\begin{tabular}{|lcccccc|}
\hline $\begin{array}{l}\text { Parameters } \\
\text { included }\end{array}$ & df & Deviance & AIC & $\begin{array}{c}\text { Likelihood } \\
\text { ratio }\end{array}$ & $\mathrm{p}$ \\
\hline $\begin{array}{l}\text { Current direction } \\
\text { and strength }\end{array}$ & 164.373 & 180.373 & & \\
$\begin{array}{l}\text { Strength } \\
\text { Direction }\end{array}$ & 1 & 175.689 & 189.689 & 11.316 & $<0.001$ \\
& 6 & 223.853 & 227.853 & 59.480 & $<0.001$ \\
\hline
\end{tabular}

During the month of June, sighting rates of minke whales were significantly higher in 4' cells with 'probable' or 'very likely' sandeel occurrence by comparison with cells where sandeel presence was 'unlikely'. In contrast, this relationship did not apply later in the season, which suggests that sandeels are only important in minke whale diet during spring. This period coincides with the main growth phase of sandeels where they have been studied in the Irish (Cameron 1959) and North Seas (Pedersen et al. 1999) when the fish are active in the water column feeding on zooplankton. These results quantitatively support the hypothesis of a change in diet between early and late seasons as suggested by Macleod et al. (2004), who based their findings on a qualitative comparison between information from the literature on sandeel and herring habitat with their minke whale distribution models that were restricted to fixed physical environmental parameters. However, Macleod et al.'s (2004) hypothesis of prespawning herring being the main prey during August and September was not corroborated by prey sampling around the Small Isles in the same months, $96 \%$ ( $\mathrm{n}=$ 26) of which consisted of sprat (Anderwald 2009). The majority of minke whale surface feeding activity in the area during this time of year occurs in the presence of multi-species flocks of seabirds (auks, kittiwakes Rissa tridactyla, gulls Larus spp. and Manx 

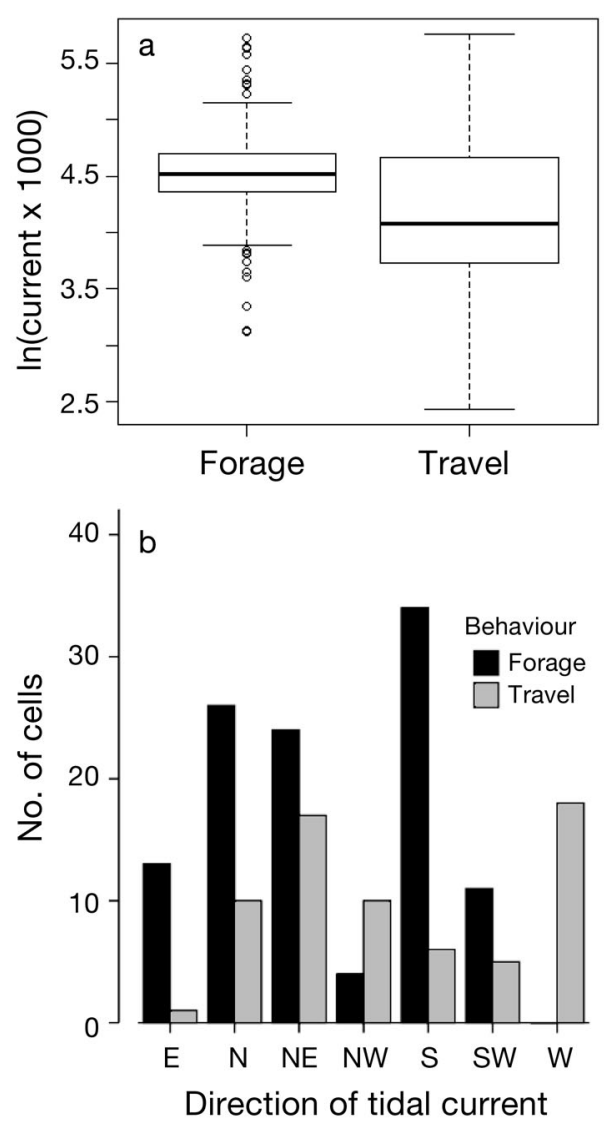

Fig. 5. Minke whale Balaenoptera acutorostrata foraging and travelling behaviour in relation to the only 2 parameters retained in the final logistic regression model: (a) current speed $\left(\mathrm{m} \mathrm{s}^{-1} \times 1000\right)$, and (b) direction of tidal current. Boxplots show median (thick line), interquartile range (IQR, box), median $\pm 1.5 \times \mathrm{IQR}$ (whiskers) and outliers (circles)

shearwaters Puffinus puffinus) that apparently take the same prey as the whales (Anderwald et al. 2011). Prespawning (i.e. adult) herring would be too large for any of these bird species to catch, and fish scales compatible with the size of adult herring were never found in either whale or seabird feeding locations during August and September 2003 and 2004.

The role of sandeel in minke whale diet in the earlier part of the season was further supported by the important contribution of SST towards explaining relative minke whale abundance during spring in the present models, both for the Small Isles (where it was the only significant parameter for May/June) and the entire eastern Hebrides. Minke whale sighting rates showed a peak towards the higher end of the spring temperature scale at around 11 to $12^{\circ} \mathrm{C}$. In the laboratory, Winslade (1974) demonstrated that swimming activity of sandeels increased when temperature was increased from 5 to $10^{\circ} \mathrm{C}$, thus making them more readily available to predators in the water column at higher temperatures. Similarly, in the field, van der Kooij et al. (2008) found that peak sandeel abundance occurred at temperatures around $9^{\circ} \mathrm{C}$. Although sandeels do not fully enter their overwintering phase until September or October, during which time they remain buried in the sand, their abundance in the water column steeply declines in July and August, which is evident from changes in commercial catches (Pedersen et al. 1999) and their lower availability to surface feeding seabirds (Wanless et al. 2004). This seasonal reduction in sandeel density within the water column probably explains why they appear to become less important to the whales. The observed temperature preferences of minke whales during spring would therefore be consistent with those water temperatures in which sandeels are more active during this time of year, even when allowing for the fact that SST (as measured in the present study) is somewhat higher than seafloor temperature (most relevant for sandeel activity) if the water is stratified. Around the Dogger Bank in the North Sea, average differences between surface and seafloor temperatures at up to ca. $60 \mathrm{~m}$ depth were mostly below $0.5^{\circ} \mathrm{C}$, and the greatest difference between seafloor temperatures at depths of 10 to $60 \mathrm{~m}$ during spring was $<3^{\circ} \mathrm{C}$ (van der Kooij et al. 2008).

A recent dietary study of common guillemots Uria aalge on the west coast of Scotland during the breeding season (Anderson 2008) identified sandeels as the main prey being fed to chicks at some of the major colonies, and the same seasonal changes in distribution with respect to sandeel occurrence as observed for minke whales, have previously been found for common guillemots across Scotland (Wright \& Begg 1997). Since sandeel presence is unlikely over most of the core study area around the Small Isles (Wright et al. 2000), this could explain the low numbers of minke whale sightings in this region during spring, followed by a movement into the area only later on in the season (Fig. 1b; see also Leaper et al. 1997, Macleod et al. 2004) when the whales appear to be feeding mainly on sprat (Anderwald 2009). Indeed, the model for May/June for the Small Isles explained only $14.9 \%$ of the deviance (making it the poorest model of all) compared with $64.2 \%$ of the deviance explained for the entire eastern Hebrides, which included the likelihood of sandeel presence as an explanatory variable. If minke whales can use water temperature to assess an area with respect to its likely productivity for sandeels in the water column, this could explain why the relative abundance of minke whales around the Small Isles in spring seemed to be dictated entirely by SST. 
A dependence on sprat in August/September would then explain the significant effect of phytoplankton concentration (as indicated by chl a concentration) in the GAM for the area around the Small Isles that occurred precisely during this part of the season. Since sprat fast during winter (Lee \& Ramster 1981), late summer and early autumn would be a crucial time for them to increase their fat reserves, and it would therefore make sense for them to aggregate in areas of high phytoplankton concentrations, and thus presumably high copepod abundance, at this time of year.

The strong effects of temporally variable environmental parameters (SST and phytoplankton concentration) on minke whale distribution in the habitat models for the west coast of Scotland appear to have more general applicability: they are consistent with large between-year shifts in the distribution of minke whales according to the fluctuating location of the Polar Front in the Barents Sea (Bjørge 2001), where the species feeds on different prey (Haug et al. 1995, 2002); Extreme differences in sighting rates between years have also been reported from the Gulf of St. Lawrence in eastern Canada (U. Tscherter pers. comm.). By contrast, tidal parameters had no influence on overall minke whale distribution, but instead showed a significant effect on foraging versus travelling behaviour at the finest spatial scale investigated in which whales exploited stronger currents within a relatively narrow range for foraging. The lack of a relationship between tidal parameters and the distribution of whales was surprising considering that minke whales are often associated with tidally active areas (Johnston et al. 2005, Ingram et al. 2007, Baumgartner 2008). However, given the extreme variations in current strength in one and the same location throughout the tidal cycle, it seems plausible that this parameter is most likely to influence minke whale behaviour in a particular area at a fine spatial scale rather than their overall distribution at the scales measured in the present study.

Because minke whales have a low energetic cost of swimming (Blix \& Folkow 1995), exploiting dynamic environmental conditions at both small and large spatial scales in order to locate prey patches would seem to be energetically profitable. In this context, the combined results of the habitat models and logistic regression on foraging versus travelling behaviour are also consistent with the spatial scales of the different environmental parameters. If the combination of depth, topography, temperature and phytoplankton concentration (i.e. the variables that were important in the habitat models) makes an area worth visiting, foraging behaviour at the local scale can then be fine-tuned according to parameters that change over a matter of hours, but in a predictable manner, such as occurs with tidal currents. These patterns of habitat use indicate that minke whales respond at appropriate scales to changes in both spatial and temporal factors relevant for determining prey distribution and abundance.

Acknowledgements. This project was financially supported by the Basler Stiftung für Biologische Forschung, British Council, Swiss Study Foundation and Sea Watch Foundation, with field work funded in part by the National Geographic Society, Eleanor Dorsey Fund and Stiftung Dr. Joachim de Giacomi. Field work was carried out under per-

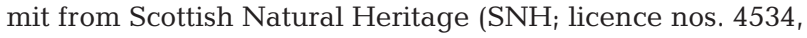
5397, 5998, 7251 and 7978). SST and chl a data were kindly supplied by the Natural Environment Research Council (NERC) Earth Observation Data Acquisition and Analysis Service (NEODAAS) at Plymouth. The analysis profited from advice by $M$. Baines, L. Barba-Villaescusa, R. Gramolini, S. Mendes, C. Paxton, G. Pierce, P. M. Holligan, F. Marubini and C. MacLeod. We also thank all our skippers and volunteer field assistants for their help and support.

\section{LITERATURE CITED}

Anderson H (2008) Common guillemot Uria aalge chick diet and bridled proportions on Scotland's west coast. MSc thesis, University of Aberdeen

Anderwald P (2009) Population genetics and behavioural ecology of North Atlantic minke whales (Balaenoptera acutorostrata). PhD thesis, University of Durham

Anderwald P, Evans PGH, Hoelzel AR, Papastavrou V (2008) Minke whale. In: Harris S, Yalden DW (eds) Mammals of the British Isles: handbook, 4th edn. The Mammal Society, Southampton, p 665-669

Anderwald P, Evans PGH, Gygax L, Hoelzel AR (2011) Role of feeding strategies in seabird-minke whale associations. Mar Ecol Prog Ser 424:219-227

> Augustin NH, Borchers DL, Buckland ST, Clarke ED, Walsh M (1998) Spatio-temporal models to improve the annual egg production method. Can J Fish Aquat Sci 55: 2608-2621

- Baker CS, Herman LM, Perry A, Lawton WS and others (1986) Migratory movement and population structure of humpback whales (Megaptera novaeangliae) in the central and eastern North Pacific. Mar Ecol Prog Ser 31: 105-119

Baumgartner MF (1997) The distribution of Risso's dolphin (Grampus griseus) with respect to the physiography of the northern Gulf of Mexico. Mar Mamm Sci 13:614-638

Baumgartner (2008) Distribution, diving behaviour and identification of the North Atlantic minke whale in Northeast Scotland. MSc thesis, University of Aberdeen

Beare DJ, Reid DG, Petitgas P (2002) Spatio-temporal patterns in herring (Clupea harengus L.) school abundance and size in the northwest North Sea: modelling spacetime dependencies to allow examination of the impact of local school abundance on school size. ICES J Mar Sci 59: 469-479

Bjørge A (2001) How persistent are marine mammal habitats in an ocean of variability? In: Evans PGH, Raga JA (eds) Marine mammals: biology and conservation. Kluwer Academic/Plenum Publishers, London, p 63-91 
Blix AS, Folkow LP (1995) Daily energy expenditure in free living minke whales. Acta Physiol Scand 153:61-66

Boran JR, Evans PGH, Rosen MJ (1999) Cetaceans of the Hebrides: seven years of surveys. In: Evans PGH, Cruz J, Raga JA (eds) European research on cetaceans 13. Proc 13th Annu Conf Eur Cetacean Soc, Valencia, Spain, 5-8 April 1999. European Cetacean Society, Valencia, p 169-174

Bradshaw CJA, Higgins J, Michael KJ, Wotherspoon SJ, Hindell MA (2004) At-sea distribution of female southern elephant seals relative to variation in ocean surface properties. ICES J Mar Sci 61:1014-1027

Buckland ST, Anderson DR, Burnham KP, Laake JL (1993) Distance sampling: estimating abundance of biological populations. Chapman \& Hall, London

Burnham KP, Anderson DR (2002) Model selection and multimodel inference: a practical information-theoretic approach, 2nd edn. Springer-Verlag, New York, NY

Cameron J (1959) Studies on the Ammodytidae of Isle of Man waters. PhD thesis, University of Liverpool

> Chenoweth EM, Gabriele CM, Hill DF (2011) Tidal influences on humpback whale habitat selection near headlands. Mar Ecol Prog Ser 423:279-289

Cotté C, Simard Y (2005) Formation of dense krill patches under tidal forcing at whale feeding hot spots in the St. Lawrence Estuary. Mar Ecol Prog Ser 288:199-210

Cotté C, Guinet C, Taupier-Letage I, Mate B, Petiau E (2009) Scale-dependent habitat use by a large free-ranging predator, the Mediterranean fin whale. Deep-Sea Res I 56:801-811

> Craven P, Wahba G (1979) Smoothing noisy data with spline functions. Numer Math 31:377-403

Dorsey EM (1983) Exclusive adjoining ranges in individually identified minke whales (Balaenoptera acutorostrata) in Washington State. Can J Zool 61:174-181

Dorsey EM, Stern SJ, Hoelzel AR, Jacobsen J (1990) Minke whales (Balaenoptera acutorostrata) from the west coast of North America: individual recognition and small-scale site fidelity. In: Hammond PS, Mizroch SA, Donovan GP (eds) Individual recognition of cetaceans: use of photoidentification and other techniques to estimate population parameters. Rep Int Whaling Comm Spec Issue 12: 357-368

Ellett DJ (1979) Some oceanographic features of Hebridean waters. Proc R Soc Edinb B 77:61-74

Ellett DJ, Edwards A (1983) Oceanography and inshore hydrography of the Inner Hebrides. Proc R Soc Edinb B 83:143-160

Evans PGH (1990) European cetaceans and seabirds in an oceanographic context. Lutra 33:95-125

Evans PGH, Borges L (1996) Associations between porpoises, seabirds and their prey in south-east Shetland, N. Scotland. In: Evans PGH, Nice H (eds) European research on cetaceans 9. Proc 9th Annu Conf Eur Cetacean Soc, Lugano, Switzerland, 9-11 February 1995. European Cetacean Society, Kiel, p 173-178

Evans PGH, Hammond PS (2004) Monitoring cetaceans in European waters. Mammal Rev 34:131-156

Evans PGH, Stirling I (2001) Life history strategies of marine mammals. In: Evans PGH, Raga JA (eds) Marine mammals: biology and conservation. Kluwer Academic/ Plenum Press, London, p 7-56

Evans PGH, Wang J (2002) Re-examination of distribution data for the harbour porpoise around Wales and the UK with a view to site selection for this species. Countryside Counc Wales Contract Sci Rep No. 634. Countryside Council for Wales, Bangor
Fauchald P, Tveraa T (2003) Using first-passage time in the analysis of area-restricted search and habitat selection. Ecology 84:282-288

Gill A, Fairbairns R (1995) Photo-identification of the minke whale Balaenoptera acutorostrata off the Isle of Mull, Scotland. In: Blix AS, Walløe L, Ulltang Ø (eds) Whales, seals, fish and man. Elsevier Science, Amsterdam, p 129-132

Guinet C, Dubroca L, Lea MA, Goldsworthy S and others (2001) Spatial distribution of foraging in female Antarctic fur seals Arctocephalus gazella in relation to oceanographic variables: a scale-dependent approach using geographic information systems. Mar Ecol Prog Ser 219: 251-264

Gunnlaugsson T (1989) Report on Icelandic minke whale surfacing rate experiments in 1987. Rep Int Whaling Comm 39:435-436

> Hammond PS, Berggren P, Benke H, Borchers DL and others (2002) Abundance of harbour porpoises and other cetaceans in the North Sea and adjacent waters. J Appl Ecol 39:361-376

Hastie GD, Wilson B, Wilson LJ, Parsons KM, Thompson PM (2004) Functional mechanisms underlying cetacean distribution patterns: hotspots for bottlenose dolphins are linked to foraging. Mar Biol 144:397-403

Hastie GD, Swift RJ, Slesser G, Thompson PM, Turrell WR (2005) Environmental models for predicting oceanic dolphin habitat in the Northeast Atlantic. ICES J Mar Sci 62: 760-770

Hastie T, Tibshirani R (1990) Generalized additive models. Chapman \& Hall, London

> Haug T, Gjøsæter H, Lindstrøm U, Nilssen KT (1995) Diet and food availability for north-east Atlantic minke whales (Balaenoptera acutorostrata) during the summer of 1992. ICES J Mar Sci 52:77-86

Haug T, Lindstrøm U, Nilssen KT (2002) Variations in minke whale (Balaenoptera acutorostrata) diet and body condition in response to ecosystem changes in the Barents Sea. Sarsia 87:409-422

> Hoelzel AR, Dorsey EM, Stern SJ (1989) The foraging specializations of individual minke whales. Anim Behav 38 : 786-794

> Holland GJ, Greenstreet SPR, Gibb IM, Fraser HM, Robertson MR (2005) Identifying sandeel Ammodytes marinus sediment habitat preferences in the marine environment. Mar Ecol Prog Ser 303:269-282

Ingram SN, Walshe L, Johnston D, Rogan E (2007) Habitat partitioning and the influence of benthic topography and oceanography on the distribution of fin and minke whales in the Bay of Fundy, Canada. J Mar Biol Assoc UK 87:149-156

> Johnston DW, Thorne LH, Read AJ (2005) Fin whales Balaenoptera physalus and minke whales Balaenoptera acutorostrata exploit a tidally driven island wake ecosystem in the Bay of Fundy. Mar Ecol Prog Ser 305:287-295

Jonsgård Å (1982) The food of minke whales (Balaenoptera acutorostrata) in northern North Atlantic waters. Rep Int Whaling Comm 32:259-262

Joyce GG, Sigurjónsson J, Víkingsson GA (1990) Radio tracking a minke whale (Balaenoptera acutorostrata) in Icelandic waters for the examination of dive-time patterns. Rep Int Whaling Comm 40:357-361

Kareiva P, Odell G (1987) Swarms of predators exhibit 'preytaxis' if individual predators use area-restricted search. Am Nat 130:233-270

Leaper R, Fairbairns R, Gordon J, Hiby A, Lovell P, Papastavrou V (1997) Analysis of data collected from a whale- 
watching operation to assess relative abundance and distribution of the minke whale (Balaenoptera acutorostrata) around the Isle of Mull, Scotland. Rep Int Whaling Comm 47:505-511

Lee AJ, Ramster JW (1981) Sprat (Sprattus sprattus): fishing areas. In: Atlas of the seas around the British Isles. Ministry of Agriculture Fisheries and Food (MAFF), Lowestoft, p 58

Lindstrøm U, Haug T, Nilssen KT (1997) Diet studies based on contents from two separate stomach compartments of northeast Atlantic minke whales Balaenoptera acutorostrata. Sarsia 82:63-68

Lindstrøm U, Haug T, Røttingen I (2002) Predation on herring, Clupea harengus, by minke whales, Balaenoptera acutorostrata, in the Barents Sea. ICES J Mar Sci 59: $58-70$

Lydersen C, Weslawski JM, Øritsland NA (1991) Stomach content analysis of minke whale Balaenoptera acutorostrata from the Lofoten and Vesterålen areas, Norway. Holarct Ecol 14:219-222

> Macleod K, Fairbairns R, Gill A, Fairbairns B, Gordon J, Blair-Myers C, Parsons ECM (2004) Seasonal distribution of minke whales Balaenoptera acutorostrata in relation to physiography and prey off the Isle of Mull, Scotland. Mar Ecol Prog Ser 277:263-274

Maravelias CD (1999) Habitat selection and clustering of a pelagic fish: effects of topography and bathymetry on species dynamics. Can J Fish Aquat Sci 56:437-450

Marubini F, Gimona A, Evans PGH, Wright PJ, Pierce GJ (2009) Habitat preferences and interannual variability in occurrence of the harbour porpoise Phocoena phocoena off northwest Scotland. Mar Ecol Prog Ser 381:297-310

McKeown BA (1984) Fish migration. Croom Helm, London, p 31-43

Mendes S, Turrell W, Lütkebohle T, Thompson P (2002) Influence of the tidal cycle and a tidal intrusion front on the spatio-temporal distribution of coastal bottlenose dolphins. Mar Ecol Prog Ser 239:221-229

Neve PB (2000) The diet of the minke whale in Greenlanda short review. In: Víkingsson GA, Kapel FO (eds) Minke whales, harp and hooded seals: major predators in the North Atlantic ecosystem. NAMMCO Sci Publ, Vol 2. Scientific Committee of the North Atlantic Marine Mammal Commission, Tromsø, p 92-96

Olsen E, Holst JC (2001) A note on common minke whale (Balaenoptera acutorostrata) diets in the Norwegian Sea and North Sea. J Cetacean Res Manag 3:179-183

> Panigada S, Zanardelli M, MacKenzie M, Donovan C, Mélin F, Hammond PS (2008) Modelling habitat preferences for fin whales and striped dolphins in the Pelagos Sanctuary (Western Mediterranean Sea) with physiographic and remote sensing variables. Remote Sens Environ 112: 3400-3412

Pedersen SA, Lewy P, Wright PJ (1999) Assessments of the lesser sandeel (Ammodytes marinus) in the North Sea based on revised stock divisions. Fish Res 41:221-241

Pierce GJ, Santos MB, Reid RJ, Patterson IAP, Ross HM (2004) Diet of minke whales Balaenoptera acutorostrata in Scottish (UK) waters with notes on strandings of this species in Scotland 1992-2002. J Mar Biol Assoc UK 84: 1241-1244

Pierpoint C (2008) Harbour porpoise (Phocoena phocoena) foraging strategy at a high energy, near-shore site in south-west Wales, UK. J Mar Biol Assoc UK 88: 1167-1173

Editorial responsibility: Yves Cherel, Villiers-en-Bois, France
Pingree RD, Griffiths DK (1978) Tidal fronts on the shelf seas around the British Isles. J Geophys Res 83:4615-4622

R Development Core Team (2006) R: A language and environment for statistical computing. R Foundation for Statistical Computing, Vienna. www.R-project.org

Reid JB, Evans PGH, Northridge SP (2003) Atlas of cetacean distribution in north-west and European waters. Joint Nature Conservation Committee (JNCC), Peterborough

Shillinger GL, Palacios DM, Bailey H, Bograd SJ and others (2008) Persistent leatherback turtle migrations present opportunities for conservation. PLoS Biol 6:e171

Simard Y, Lavoie D, Saucier FJ (2002) Channel head dynamics: capelin (Mallotus villosus) aggregation in the tidally driven upwelling system of the Saguenay-St. Lawrence Marine Park's whale feeding ground. Can J Fish Aquat Sci 59:197-210

Smith RC, Dustan P, Au D, Baker KS, Dunlap EA (1986) Distribution of cetaceans and sea-surface chlorophyll concentrations in the California Current. Mar Biol 91: 385-402

Southward AJ, Boalch GT, Maddock L (1988) Fluctuations in the herring and pilchard fisheries of Devon and Cornwall linked to change in climate since the 16th century. J Mar Biol Assoc UK 68:423-445

Stevick PT, McConnell BJ, Hammond PS (2002) Patterns of movement. In: Hoelzel AR (ed) Marine mammal biology: an evolutionary approach. Blackwell, Oxford, p 185-216

Thiele D, Chester ET, Gill PC (2000) Cetacean distribution off Eastern Antarctica $\left(80-150^{\circ}\right.$ E) during the Austral summer of 1995/1996. Deep-Sea Res II 47:2543-2572

- Tinbergen N, Impekoven M, Franck D (1967) An experiment on spacing-out as a defense against predation. Behaviour 28:307-321

Valiela I (1995) Marine ecological processes, 2nd edn. Springer-Verlag, New York, NY

van der Kooij J, Scott BE, Mackinson S (2008) The effects of environmental factors on daytime sandeel distribution and abundance on the Dogger Bank. J Sea Res 60:201-209

Walsh PD (1996) Area-restricted search and the scale dependence of path quality discrimination. J Theor Biol 183:351-361

- Wanless S, Wright PJ, Harris MP, Elston DA (2004) Evidence for decrease in size of lesser sandeels Ammodytes marinus in a North Sea aggregation over a 30-yr period. Mar Ecol Prog Ser 279:237-246

Winslade P (1974) Behavioural studies on the lesser sandeel Ammodytes marinus (Raitt) III. The effect of temperature on activity and the environmental control of the annual cycle of activity. J Fish Biol 6:587-599

> Wood SN (2004) Stable and efficient multiple smoothing parameter estimation for generalized additive models. J Am Stat Assoc 99:673-686

Wood SN (2006) Generalized additive models: an introduction with R. Chapman \& Hall/CRC Press, Boca Raton, FL

Wright PJ, Begg GS (1997) A spatial comparison of common guillemots and sandeels in Scottish waters. ICES J Mar Sci 54:578-592

Wright PJ, Pedersen SA, Donald L, Anderson C, Lewy P, Proctor R (1998) The influence of physical factors on the distribution of lesser sandeels and its relevance to fishing pressure in the North Sea. ICES CM 1998/AA:3. ICES, Copenhagen

- Wright PJ, Jensen H, Tuck I (2000) The influence of sediment type on the distribution of the lesser sandeel, Ammodytes marinus. J Sea Res 44:243-256 